\title{
Determinants of capital structure in Irish SMEs
}

\begin{abstract}
This paper presents an empirical examination of firm characteristic determinants of the capital structure of a sample of 299 Irish small and medium sized firms (SMEs). Hypotheses formulated from pecking order and agency theories incorporating a financial growth life cycle approach are tested on a number of multivariate regression models. Results suggest that age, size, level of intangible activity, ownership structure and the provision of collateral are important determinants of the capital structure in SMEs. A generalization of Zellner's (1962) Seemingly Unrelated Regression approach (SUR) is used to examine industry effects and to test the stability of parameter estimates across sectors. Results suggest that the influence of age, size, ownership structure and provision of collateral is similar across industry sectors, indicating the universal effect of information asymmetries. Firms overcome the lack of adequate collateralizable firm assets in two ways; by providing personal assets as collateral for business debt, and by employing additional external equity to finance research and development projects.
\end{abstract}

Keywords Capital structure, SME, Zellner's SUR model.

JEL Classifications E44 G21 G32 L26 


\section{Introduction}

The means of financing employed for positive net present value projects has important implications for the firm. The cumulative effect of these discrete financing decisions results in the capital structure of the firm, the composition of which has long been a focus of research in the corporate finance discipline. Theoretical discourse on the capital structure of the firm originates from the irrelevance propositions of Modigliani and Miller (1958), stating that the capital structure of the firm was independent of its cost of capital, and therefore of firm value. The propositions of 1958 were based on a number of unrealistic assumptions, and in 1963 Modigliani and Miller introduced taxes into the model. This led to the development of the trade-off theory of capital structure, whereby the tax-related benefits of debt were offset by costs of financial distress. Alternative approaches, based on asymmetric information between 'inside' managers and 'outside' investors, include signalling theory (Ross, 1977) and the pecking order theory (Myers, 1984, Myers and Majluf, 1984). The latter postulates that when internal sources of finance are not sufficient for investment needs the firm has a preference to raise external finance in debt markets, with equity issues the least preferable source. A further approach considered a nexus of relationships, characterised as principal-agent relationships, and the potential agency costs on the firm (Jensen and Meckling, 1976).

A common refrain in early academic studies on the capital structures of SMEs was of a 'neglected' and 'much ignored' area of research (e.g. Zingales, 2000). The burgeoning literature in the field in the past two decades has partially satisfied that deficit, although the topic is still in its infancy. The approach commonly adopted in previous studies is to test hypotheses formulated from capital structure theories by testing static multivariate regression models on panel data (e.g. Michaelas et al., 1999, Chittenden et al., 1996, Hall et al., 2004, Sogorb Mira, 2005, Esperanca et al., 2003, Fu et al., 2002, Cassar and Holmes, 2003, Heyman et al., 2008). These studies investigate the relationship between firm characteristic variables and the means of financing chosen, typically employing debt ratios as dependent variables. Studies testing multivariate models employing equity as a dependent variable are rare $(\mathrm{Ou}$ and Haynes, 2006, Fluck et al., 1998), despite the fact that internal equity is the most important source of financing for SMEs. Additionally, there is a consistency in the independent variables commonly selected. Hall et al., (2000, p.300) note that: "From consideration of the previous studies of the determinants of the capital structure of small enterprises it becomes clear that profitability, growth, asset structure, size and age and possibly industry are, prima facie, likely to be related to capital structure."

Furthermore, a number of studies examine whether there are inter-industry differences in capital structures, due primarily to differences in asset structure and growth rates. Empirical evidence of sectoral effects is mixed, with studies both supporting (Hall et al., 2000) and failing to support this hypothesis. Examples of the latter include Balakrishnan and Fox (1993) who conclude that firm specific characteristics are more important than structural characteristics of industry, and Jordan et al. (1998) who find that financial and strategy variables have far greater explanatory power than industry specific effects.

In this paper we investigate the applicability of theories of capital structure in a sample of Irish SMEs by empirically testing the effect of firm characteristics on sources of debt and equity employed. Additionally, we examine sectoral differences 
in the financing decision using a generalisation of Zellner's (1962) seemingly unrelated regression (SUR) approach. We propose to add to the literature in a number of ways. Firstly, whilst previous empirical theory testing studies in SME finance tested multivariate regression models on panel data (e.g. Chittenden et al., 1996, Hall et al., 2004), we apply regression analysis on survey data, which is novel in finance (De Jong and Van Dijk, 2007). Secondly, we employ sources of internal and external equity, along with debt as dependent variables in multivariate models. This approach differs from previous studies, which typically tested regression models employing short- and long-term debt as dependent variables (e.g. Sogorb Mira, 2005). Thirdly, we employ detailed data on the provision of collateral by respondents as an explanatory variable. Fourthly, we use the SUR approach to test the stability of parameter estimates across sectors, differing from the dummy variable approach commonly adopted in previous studies (e.g. Chittenden et al., 1996). The advantage of the SUR approach is that, whilst the dummy variable approach assumes that the response of each sector to each independent variable is identical, the SUR model evaluates how independent variables vary as between sectors. Finally, this paper contributes to the growing number of country-specific studies on the capital structure decision in SMEs by providing original empirical evidence in the Irish context, utilising a sample not restricted by sector or location.

Our results imply that firms source finance in a manner consistent with Myers' (1984) pecking order theory, highlighting the importance of profitability in funding the sector. Results indicate that firms with a high level of fixed assets overcome problems of asymmetric information by pledging collateral to secure debt finance. When there are insufficient firm assets to secure business loans, the personal assets of the firm owner are an important source of collateral.

This paper proceeds as follows: Firstly, agency and pecking order theories are reviewed through a life cycle growth perspective and hypotheses are formulated. The sample frame, data collection process and variables are described in section 3 . The method of analysis is described in section 4, and the empirical results are presented and discussed in section 5. Section 6 concludes, followed by suggestions for further research and policy implications in section 7 .

\section{Theoretical review and formulation of hypotheses}

Capital structure theories developed since the original Modigliani and Miller propositions may be broadly classified in three types; namely static trade-off theory, agency theory and theories based on information asymmetries. Whilst these theories were developed in the field of corporate finance, they have been profitably employed in SME studies. A review of empirical evidence reveals a number of relevant theories for our study.

Introducing taxes into their irrelevance model, Modigliani and Miller (1963) highlighted the benefits conferred by debt finance in reducing a firm's taxation liability. DeAngelo and Masulis (1980) subsequently proposed the static trade-off theory, whereby the advantage conferred by debt in the form of a decreased tax bill was offset by an increase in business risk. They proposed a theoretical optimum level of debt for a firm, where the present value of tax savings due to further borrowing is just offset by increases in the present value of costs of distress. Empirical investigations of the trade-off theory in the SME literature do not find evidence to 
support this theory (Michaelas et al., 1999, Sogorb Mira, 2005). This may be due to lower levels of profitability in SMEs, compared with the corporate sector (Pettit and Singer, 1985). Firms with lower levels of profitability have less use for debt-tax shields, ceteris paribus. Small firms are also at a greater risk of financial distress and "young firms are more failure prone than older ones" (Cressy, 2006, p.103). The debttax shield is thus less valuable for SMEs. Furthermore, the Irish corporate tax rate of 12.5 percent is one of the lowest in the world at present. Because of the combination of these factors, we contend that the static trade-off theory is not a first order consideration for Irish SMEs. In seeking explanations for the financing decision, we must therefore examine alternative theories. Bearing in mind that the capital structure of the firm is not static and evolves over time, we incorporate the financial growth life cycle approach (Berger and Udell, 1998) in consideration of these theories and formulation of hypotheses.

\subsection{Hypotheses derived from the pecking order theory}

Myers (1984) and Myers and Majluf (1984) developed the pecking order theory (POT) based on the premise that 'inside' management are better informed of the true value of the firm than 'outside' investors. These information asymmetries result in varying costs of additional external finance, as potential investors perceive equity to be riskier than debt. They propose that firms seek to overcome problems of undervaluation arising from information asymmetries, preferring to finance investment projects with internal funds in the first instance. When internal equity is exhausted, firms use debt financing before resorting to external equity. Authors state that the POT is even more relevant for the SME sector because of the relatively greater information asymmetries and the higher cost of external equity for SMEs (Ibbotson et al., 2001). Additionally, a common phenomenon in the sector is the desire of firm owners to retain control of the firm and maintain managerial independence (Chittenden et al., 1996, Jordan et al., 1998). These factors suggests that SME owners source their capital from a pecking order of, first, their "own" money (personal savings and retained earnings); second, short-term borrowings; third, longer term debt; and, least preferred of all, from the introduction of new equity investors, which represents the maximum intrusion (Cosh and Hughes, 1994). Empirical evidence supports the applicability of the POT in explaining the financing of SMEs (Chittenden et al., 1996, Michaelas et al., 1999, Berggren et al., 2000, Lopez-Gracia and Aybar-Arias, 2000, Sogorb Mira, 2005, Ou and Haynes, 2006). These studies emphasize that small firms rely on internal sources of finance and external borrowing to finance operations and growth, and only a very small number of firms use external equity. A number of studies report that firms operate under a constrained pecking order, and do not even consider raising external equity (Holmes and Kent, 1991, Howorth, 2001).

Adherence to the POT is dependent not only on demand-side preferences, but also on the availability of the preferred source of financing. The supply of finance depends on many factors, particularly the stage of development of the firm. The most important source of funding for start-up and nascent firms are the personal funds of the firm owner, and funding from friends and family (or 'F-connections')(Avery et al., 1998). Thus we propose that:

H1: The use of personal savings of the SME owner and 'f connections' is negatively related with age. 
As the size and age of the firm are inextricably linked, a number of issues are correlated. Firstly, start-up and early stage firms are generally smaller than mature and older firms, and have a greater proportionate reliance on the personal financial resources of the firm owner. Therefore, we propose the hypothesis:

$\mathrm{H} 2$ : The use of personal savings of the SME owner and 'f connections' is negatively related with size.

If the firm is successful as it grows and matures, retained profits are reinvested in current and capital projects, augmenting personal sources of funding. A continued preference for internal equity increasingly relies on accumulated retained profits as the firm survives and matures. Consistent with Myers' (1984) POT, we propose the hypotheses:

H3: The use of retained profits is positively related with age.

H4: The use of retained profits is positively related with size.

Start-up and early stage firms may face particular difficulty in sourcing finance for investment for a number of reasons. Firstly, internal equity is restricted, as retained profits are typically insufficient, and the personal resources of the firm owner and ' $\mathrm{f}$ ' connections may be limited. Secondly, a combination of information asymmetries and potential agency problems related to the lack of a trading history restricts access to external debt, which may be exacerbated by the lack of collateralizable assets. For these reasons, start-up and early stage firms may resort to external equity, particularly private investors and business angels (Berger and Udell, 1998). SME owners willing to cede control may attract funding from venture capitalists, especially firms with high-growth potential. Government grant schemes and tax incentive equity schemes may also be important sources of external equity financing for fledgling firms, especially in strategically targeted sectors (e.g. high-tech). This is especially true in the Irish case, as government equity schemes are targeted at nascent firms with highpotential for exports and employment growth. Thus, we propose the hypothesis:

H5: The use of external equity is negatively related with age.

Venture capitalists typically invest in firms with high-growth potential, investing at a stage when a product or service has been pre-tested. Venture capital investment is generally positively correlated with the size of a firm, as a high rate of return is required in a relatively short period of three to eight years (Smith and Smith, 2004). Firms sourcing additional venture capital funding have typically received previous equity funding, and have grown past start-up size. Thus we propose the hypothesis:

H6: The use of external equity is positively related with size.

Firms with a high demand for additional capital may resort to a greater variety of sources of funding than firms with lesser needs. For firms possessing a high-level of no-lien fixed assets, debt is the preferred choice to fund positive NPV projects when internal funding is insufficient, according to the POT. High growth firms with insufficient internal funding and inadequate non-collateralized fixed assets are less averse to ceding control, and resort to external equity from new investors (Cressy and Olofsson, 1997, Hogan and Hutson, 2005). This may be especially true for firms engaged in a high level of intangible activity relative to their turnover (Berggren et al, 2000). Therefore, we propose that:

H7: The use of external equity is positively related with intangible activity. 
Firms engaged in a high level of intangible activity relative to their turnover are most likely to report a continuing financial constraint (Westhead and Storey, 1997). This is particularly true in the case of young firms of limited turnover, as R\&D activity generally requires large amounts of capital without providing immediate returns on investment (Hall, 2002). Such firms may also have difficulty accessing debt markets because of a lack of sufficient collateralizable assets. Thus, we propose the hypothesis:

H8: The use of retained profits is negatively related with intangible activity.

Empirical evidence suggests that the ownership structure of a firm has a significant effect on the desire for control, with consequent implications for financing. A number of authors suggest that family controlled firms have a greater desire for control and exhibit an aversion to external financing (e.g. Mishra and McConaughy, 1999). Watson and Wilson (2002, p.575) state "that closely-held firms have both greater opportunities and incentives to retain profits in the business". For closely-held firms, we propose that control is the primary determinant in the financing decision:

H9: The use of internal equity is positively related with closely-held ownership.

\subsection{Hypotheses derived from agency theory}

Jensen and Meckling (1976) outlined a number of potentially costly principal-agent relationships in publicly quoted corporations that may arise because the agent does not always conduct business in a way that is consistent with the best interest of the principals. The firm's security holders (debtholders and stockholders) are seen as principals and the firm's management as the agent, managing the principals' assets. Whilst a number of these relationships are relevant for SMEs, the primary agency conflict in small firms is generally not between owners and managers, but between inside and outside contributors of capital (Hand et al., 1982). Potential agency problems in SMEs are exacerbated by information asymmetries resulting from the lack of uniform, publicly available detailed accounting information. The primary concern for outside contributors of capital arises from moral hazard, or the possibility of the SME owner changing his behavior to the detriment of the capital provider after credit has been granted. This is because the firm owner has an incentive to alter his behavior ex post to favor projects with higher returns and greater risk. Debt providers seek to minimize agency costs arising from these relationships by employing a number of lending techniques. Baas and Schrooten (2006) propose a classification of four lending techniques - transactions-based or 'hard' techniques include asset-based lending, financial statement lending, small business credit scoring lending and the 'soft' technique of relationship lending. In practice, lending to SMEs by banks is frequently collateral-based (Kon and Storey, 2003). The pervasiveness of the use of collateral is confirmed by a number of empirical studies, for example; Black et al. (1996) find that the ratio of loan size to collateral exceeds unity for 85 percent of small business loans in the UK; Berger and Udell (1990) report that over 70 percent of all loans to SMEs are collateralized. Even for firms with positive cash flow financial institutions typically require collateral (Manove et al., 2001). Thus, we propose the hypothesis:

H10: The use of debt finance is positively related with the provision of collateral. 
Potential agency problems are not constant over the life cycle of the firm. Firms at the start-up stage typically experience the greatest informational opacity problems, and may not have access to debt financing. As a firm becomes established and develops a trading and credit history, reputation effects alleviate the problem of moral hazard, facilitating borrowing capacity (Diamond, 1991). Additionally, as the firm grows it accumulates assets in the form of inventory, accounts receivable and equipment which may be used to collateralize debt (Berger and Udell, 1998). The firm may also have increased fixed assets in the form of land and buildings on which it can secure mortgage finance. Long term debt is typically secured on collateralizable fixed assets, and consequently its maturity matches the maturity of the pledged asset (Heyman et al., 2008). Therefore, the use of long term debt is expected to increase initially, and decrease at a later stage as long term debt is retired and the firm increasingly relies on accumulated retained profits. Our next hypothesis is:

H11: The use of long term debt is negatively related with age.

Firm size is also an important factor in accessing debt finance (Audretsch and Elston, 1997). There are a number of reasons for this. Firstly, it may be relatively more costly for smaller firms to resolve information asymmetries with debt providers. Consequently, smaller firms may be offered less debt capital (Cassar, 2004) or capital at a higher cost than larger firms (Baas and Schrooten, 2006). Secondly, transaction costs are typically a function of scale and may be higher for smaller firms (Titman \& Wessels, 1988, Hamilton and Fox, 1998). Thirdly, bankruptcy costs and size are inversely related. Cosh and Hughes (1994) propose that this predisposes smaller firms to use relatively less debt than larger firms. Therefore, we propose that:

H12: The use of debt finance is positively related with size.

Financial institutions typically do not advance debt finance to firms engaged in a high level of research and development (R\&D) in the absence of collateralizable fixed assets. $R \& D$ expenditure is generally intangible activity, and thus there may be no realizable residual value on completion of a project (Storey, 1994). Additionally it frequently involves as-yet-unproven technology, and requires specialist and often highly-technical knowledge and expertise to conduct a valuation. This proves unattractive to debt providers, due to the presence of significant information asymmetries. Empirical evidence finds that firms investing large sums of money in R\&D employ relatively little debt (Bougheas, 2004, Smart et al., 2007). Thus, we propose:

H13: The use of debt finance is negatively related to intangible activity, ceteris paribus.

Access to tangible assets is not constant across industry sectors. Some sectors (e.g. manufacturing) typically have a greater concentration of tangible assets, whilst the asset structure of firms in other sectors is primarily composed of intangible assets (e.g. computer services). Firms with lien-free tangible assets may have greater access to debt finance than firms lacking such assets. The importance of inter- and intrasectoral differences in accessing debt finance is confirmed in a number of studies reporting a significantly positive relationship between long-term debt and fixed assets (Van der Wijst and Thurik, 1993, Chittenden et al., 1996, Jordan et al., 1998, Michaelas et al., 1999). Therefore, we propose the hypotheses:

H14: The use of debt finance is positively related with sectors typified by a greater amount of tangible fixed assets. 
There are significant differences between short- and long-term debt contracts, not only in the collateral required to secure the debt, but also in the purposes for which the finance is required. Short-term debt is generally sourced to cover temporary deficits (Esperanca et al., 2003), which lowers the importance of firm or owner characteristics. Use of short-term debt is more likely to be determined by levels of profitability than the size or age of the firm, for example, although it may be dependent on the capacity of the firm to provide suitable collateral.

\section{Data collection and variables}

The sample frame employed for this study is the Business World 'Next 1,500' list of firms. This list is compiled from a number of sources, including the companies registration office (CRO), print and internet media sources, and the National Directory Database (NDD), and is maintained and updated annually. These firms are classified as having at least 20 employees. The list was substantially refined and modified to obtain a list of firms consistent with the aims of the study and within the parameters the European Commission (2003) definition of an SME, with an upper bound of 250 employees. Approximately one third of the firms were subsidiaries of multinational parents, and these firms were excluded from the study. Financial firms were also left out, as their capital structure may be determined by capital requirements. Because of the lower bound of 20 employees, micro enterprises and small firms with between 10 and 20 employees are not represented in the listing. An advantage of this sampling frame is that it is not confined to particular sectors or geographical regions, although it is not representative of the total Irish SME population in the strictest sense, because it contains predominantly 'medium sized' surviving firms. Distributing questionnaire surveys using a multimode approach yielded 299 responses from a sample of 702 eligible firms, representing a response rate of 42.6 percent. This is a robust response rate when compared with response rates of 10 percent and less reported in previous surveys (Curran and Blackburn, 2001). We attribute this high rate to a number of elements in the research design, including multiple contacts, the salience of the subject for respondents and cognitive and design elements of the survey instrument. A detailed profile of the age, turnover and sectoral composition of respondents is provided in table 1.

\section{Insert table 1 approximately here.}

\subsection{Specification of dependent and independent variables}

SME owner-manager's personal income is interrelated with the income of the firm, and so they are reluctant to disclose detailed financial information about their business (Ang, 1991, Avery et al., 1998). In conducting the National Survey on Small Business Finances (NSSBF) in the United States, researchers reported difficulties in eliciting data on firm financing, particularly absolute amounts (Cox et al, 1989). Additionally, there were often inaccuracies in the amounts reported (Cox et al, 1989). We requested data on financing as a percentage of total financing rather than absolute amounts due to the well-documented reticence of SME owners in disclosing this data. Although percentages reported may be slightly inaccurate, the methodology used greatly increased response rates as 92.5 percent of respondents provided useable 
replies to this question. The dependent variables used in this study are the sources of finance expressed as a percentage of total financing.

\section{Insert table 2 approximately here.}

Means and standard deviations of dependent variables across sectors are provided in table 3, indicating statistically significant differences in cross-sectional capital structures. Results suggest prima facie evidence for sectoral differences in financing choice, denoted by statistically significant differences in the use of retained profits, long term debt and external equity. The Anova does not account for differences in characteristics such as firm age, size and ownership structure as between sectors. Inter industry differences are examined using an SUR approach, and results are discussed in section 5 .

\section{Insert table 3 approximately here.}

The independent or firm characteristic variables are chosen to test the hypotheses formulated in the previous section, and are described in table 4 below. A number of independent variables are directly observable, such as the age and size of the firm, and the assets pledged to secure business loans. Other variables are defined by proxy. Expenditure on $R \& D$ as a determinant of financing choice has been examined in previous research as a proxy for future growth opportunities (Long and Malitz, 1985, Titman and Wessels, 1988, Michaelas et al., 1999). We examine relative expenditure on $R \& D$ as a measure of the intangible activity of respondents, rather than an intangible asset or a growth opportunity, as intangible activity only manifests itself as a growth opportunity if successful. The ownership variable is defined as a dichotomous dummy variable, representing closely held or family ownership of the firm.

\section{Insert table 4 approximately here.}

Correlation among independent variables may pose problems in interpreting regression coefficients. This is not a problem of model specification, but of data (Hair et al., 2006). Pearson product moment coefficients presented in table 5 indicate the magnitude and direction of the association between the independent variables. A number of independent variables are correlated at the 0.01 level of significance, and in these instances we reject the null hypothesis that there is no association between the variables. The moderate magnitude of the correlations does not suggest a high degree of first-order collinearity among the independent variables.

\section{Insert table 5 approximately here.}

Although the magnitude of correlation coefficients is moderate, a lack of high correlation values does not ensure absence of collinearity, as the combined effect of two or more independent variables may cause multicollinearity. The conventional measures for multicollinearity are tolerance and the variance inflation factor (VIF). The tolerance value is the amount of an independent variable's predictive ability that is not predicted by the other independent variables in the equation (Hair et al, 2006). A tolerance value of 1.00 indicates that a variable is totally unaffected by other independent variables. Analysis of the tolerance values and VIFs in table 6 indicates 
that multicollinearity does not pose a problem. The hypothesized relationship between variables is presented in table 7 as a comparison with the direction of the regression coefficients.

\section{Method of analysis}

The hypotheses formulated in section 2 were empirically tested using static linear regression models, employing sources of finance and firm characteristics as dependent and independent variables respectively. The model tested for each of the six dependent variables is represented by:

$$
\mathrm{Y}=\beta_{0}+\beta_{1} A G E+\beta_{2} S I Z E+\beta_{3} R \& D+\beta_{4} O W N+\beta_{7} O W N C O L L+\beta_{8} E X T C O L L+\varepsilon
$$

We ran cross-sectional OLS-regressions using data provided by all respondents, initially ignoring differences in asset structure and other sectoral factors. We investigate the influence of sectoral effects on the financing decision by estimating a set of regression equations, one for each industry sector, and examining how the observed relationships change from equation to equation. Thus, for each of the six independent variables six additional parameter coefficients per industry are estimated. This seemingly unrelated regression (SUR) system, developed by Zellner (1962), comprises several individual relationships that are linked by contemporaneous crossequation error correlation. Because the errors of the equations are correlated, the SUR estimator is more efficient, as it takes account of the matrix of correlations of all equations (Baltagi, 2005).

Previous studies have employed a variety of approaches to examine industry effects, including; a one-way analysis of variance (Esperanca et al., 2003), using industry dummies (Michaelas et al., 1999) and employing both industry constant and industry slope dummies (Hall et al., 2000). The dummy approach commonly used calculates an intercept dummy, suggesting that the sectoral impact is unrelated to the independent variables. We contend, however, that response to the independent variables varies as between sectors. Testing these effects using the OLS dummy approach would require estimating slope and intercept dummies for every variable, thus adding another 30 variables to the right hand side of the regression model. This in itself would reduce the efficiency of the OLS estimates. Whilst this approach has been adopted in previous studies (e.g. Hall et al., 2004), it would greatly reduce the degrees of freedom in our models and weaken the generalizability of the regression results. Maximizing the degrees of freedom improves generalizability and addresses both model parsimony and sample size concerns (Hair et al., 2006).

\section{Empirical results}

Results of the OLS regression analyses are statistically significant for all six dependent variables, and are presented in table 6 . The statistically significant negative relationship between size of the firm and use of the personal funds of the firm owner and ' $\mathrm{f}$ ' connections reflects the importance of personal resources of the firm owner in funding firms with low turnover. This source of finance is typically of greatest importance in younger firms, although we reject the hypothesized negative relationship between it and age of the firm as it is not statistically significant. These results suggest that contribution of firm owners' personal equity is important not only 
at start-up, but throughout the life-cycle of the firm, particularly in the smallest firms. Use of personal assets of the firm owner to secure business debt is positively related with use of funds from personal sources and ' $\mathrm{f}$ ' connections. This finding suggests that firm owners willing to supply personal funds as equity for investment are also most likely to supply 'quasi-equity' to the firm. This result provides empirical evidence of the personal commitment of small business owners in securing business loans outlined by (Black et al., 1996, Voordeckers and Steijvers, 2006, Cressy, 1993, Avery et al., 1998), and explains the provision of debt finance to start-up and nascent firms (Fluck et al., 1998, Berger and Udell, 1998). This finding also underlines the significant personal risk assumed by owners of SMEs, and emphasises a contribution that is commonly understated as it is not immediately evident from balance sheet figures.

\section{Insert table 6 approximately here.}

Relationships between firm characteristic variables and use of retained profits provide support for a number of the propositions of pecking order and agency theories. Statistically significant positive relationships between retained profits and the firm age and size variables support hypotheses three and four, highlighting the reliance of firms on accumulated internal equity over time. Additionally, the use of retained profits is significantly negatively related with both types of collateral, suggesting that debt is employed when internal equity is insufficient for investment needs. Consistent with the findings of previous studies (Sogorb Mira, 2005, Heyman et al., 2008), this result highlights the importance of profitability in funding the sector.

Expenditure on R\&D is significantly negatively related to use of retained profits, and positively related to use of external equity. This finding supports Bougheas' (2004) view that liquidity constraints due to inadequate retained profits necessitates additional resources for investment in $R \& D$. The result provides evidence that SMEs committing a large percentage of turnover to expenditure on R\&D may be restricted in their access to financing due to the nature of their assets (Bester, 1985) and their activities. Additionally, the positive relationship between use of external equity and expenditure on $R \& D$ is consistent with studies indicating that firms with a higher level of investment in innovation are less averse to ceding control (Berggren et al., 2000, Hogan and Hutson, 2005). An important qualification in this respect is the ownership structure of the firm, as the significant negative relationship between ownership and use of external equity indicates a greater desire for control among closely held firms (Poutziouris, 2003, Watson and Wilson, 2002, Poutziouris et al., 1998). This result is unsurprising, although it provides further evidence of how the desire to maintain managerial independence and retain control of the firm impacts the financing decision, even if this means passing up growth opportunities (Storey, 1994, Poutziouris, 2001).

The statistically significant positive relationship between use of long term debt and size of the firm supports the hypothesis that size is positively related to use of long term debt, and is consistent with extant empirical evidence (Michaelas et al., 1999, Sogorb Mira, 2005). The significant negative relationship between use of long term debt and age of the firm indicates that firms become increasingly reliant on internal equity as debt is retired. This result provides further evidence of the importance of profitability in funding the sector, and suggests that firms are funded in a manner consistent with the POT. Importance of access to lien-free collateralisable 
assets in securing debt finance is emphasized by the statistically significant positive relationship between the provision of collateral secured on the assets of the firm and short and long term debt. These results provide empirical evidence of the proclivity of financial institutions to use asset based lending techniques in seeking to overcome potential problems of moral hazard (Coco, 2000). They are also consistent with the previous finding that debt financing is strongly related to collateral, rather than profitability as might be expected in an efficient market (Chittenden et al., 1996). Personal commitment of the firm owner is emphasized by the statistically significant positive relationship between provision of the firm owner's personal assets as collateral to secure short-term debt. This confirms previous empirical findings (Binks et al., 1988, Cressy, 1993), and suggests that firm owners provide personal assets as collateral for short-term rather than long-term debt.

Whilst the explanatory power of our model employing short-term debt as a dependent variable is low, it highlights the temporary nature of this source of finance. Esperanca et al., (2003) explain the lack of statistical significance for short term debt as being due to the temporary nature of deficits covered by short-term debt, lowering the importance of purely fiscal or firm characteristic considerations. A comparison of the direction in both hypothesised and actual relationships between dependent and independent variables is presented in table 7.

\section{Insert table 7 approximately here.}

The regression results presented in table 6 indicate the relationships between firm characteristics and sources of financing for all respondents. Results of the SUR models presented in tables 8 to 13 indicate differences in the stability and variability of regression coefficients across sectors. One contribution of the SUR model is that the standard errors of the estimates are reduced, and it is therefore a more efficient estimator of coefficients. Comparison of t statistics of coefficients in table 6 with those in tables 8 to 13 reveals evidence of slightly increased efficiency.

\section{Insert tables 8 to 13 approximately here.}

Extant empirical evidence of sectoral effects on the capital structures of SMEs is contradictory. Whilst results presented by Michaelas et al. (1999) support this hypothesis, Balakrishnan and Fox (1993) state that firm specific characteristics are more important than sectoral effects. Results from our SUR models suggest support both positions. Firstly, the influence of a number of firm characteristic independent variables is similar across sectors. Results from the OLS regression indicate a negative relationship between firm size and the use of personal funds of the firm owner and ' $\mathrm{f}$ ' connections, as this source forms a greater percentage of investment finance in firms with low turnover, ceteris paribus. SUR results presented in table 8 show that this negative relationship is replicated in models for all but one sector, and is statistically significant for 'all respondents', the 'metal manufacturing and engineering' and 'other manufacturing' sectors. This is not an unexpected result as the large amounts of investment capital required by manufacturing sectors are not typically sourced from personal resources. Another relationship for the model including all respondents replicated in three sectors is the positive relationship between the personal sources of equity of the firm owner with the pledging of personal assets as collateral for business loans. This relationship is positive for all 
sectors, and is statistically significant in respect of the 'hotel, catering, retail and distribution', 'other services' and 'other' sectors. These results emphasize a central feature of SME financing - the contribution of personal resources by the firm owner, although sectoral differences are not apparent.

Results for SUR models employing retained profits as a dependent variable suggest that the influence of firm characteristics is similar across a number of sectors. The statistically significant positive relationship between the use of retained profits and size is repeated in respect of the 'manufacturing' and 'hotel, catering, wholesale and retail' sectors, possibly reflecting the relatively larger turnover in these sectors. The negative relationship between use of retained profits and the provision of collateral to secure debt is statistically significant for models including all respondents, the 'hotel, catering, retail and distribution', 'other services' and 'other' sectors. These results suggest similarities in adherence to Myer's (1984) pecking order of finance across sectors. One of the explanations offered for the adherence of SMEs to the POT is the desire of firm owners to retain control of the firm and maintain independence, particularly in closely held firms. This explanation is supported by the significant positive relationship between the use of retained profits and closely held firms for the models including all respondents, the 'metal manufacturing and engineering' and 'other' sectors presented in table 9. Results also indicate a statistically significant negative relationship between use of external equity and closely held ownership in models containing all respondents, the 'metal manufacturing and engineering, 'hotel, catering, retail and distribution' and 'other' sectors presented in table 10. These results suggest that the issue of control is determined by ownership structure, rather than differing across sectors.

Results of the OLS regression models presented in table 6 highlight the importance of collateral in sourcing short-and long-term debt. Results of the SUR models presented in table 13 reveal statistically significant positive relationships between use of total debt and the assets of the firm provided as collateral for all models, except the 'other' sector. Results also indicate statistically significant positive relationships between short term debt and firm assets provided as collateral for all sectors except 'other services' and 'other' sectors. These results are not replicated for long term debt, however, and so we reject hypotheses 10 and 14.

Results presented in tables 11 and 13 reveal a statistically significant positive relationship between the pledging of personal assets to secure business loans and the use of short term debt and total debt respectively for firms in the "computer software development and services' sector. Consistent with previous studies (Fluck et al., 1998, Berger and Udell, 1998), this result suggests that firms in the sector secure firm debt using personal assets due to the lack of adequate tangible firm assets. The statistically significant negative relationship between the use of external equity and the provision of firm assets to secure firm debt for firms in this sector implies further support for this proposal. These results are consistent with agency theory, and provide evidence of the reliance of financial institutions on asset-based lending techniques to overcome potential moral hazard problems.

Additionally, these results are consistent with the High-Technology Pecking Order Hypothesis (HTPOH) which proposes that high-technology firms requiring additional finance will seek external equity before debt (Hogan and Hutson, 2005). Whilst results from our study suggest that respondents in the 'computer software development and services' sector provide personal and firm assets to secure debt finance, the statistically significant positive relationship between the use of external equity and size for firms in this sector shown in table 10 indicates that larger firms use 
greater amounts of external equity, ceteris paribus. This suggests that smaller firms in this sector may have difficulty in securing external equity, thus employing debt finance. Lack of tangible firm assets to secure this funding means that firm owners must provide personal assets on which to secure firm debt.

Another significant feature of debt and equity markets for SMEs is highlighted by the relationship between the use of debt and expenditure on $R \& D$. The relationship between the use of short term debt and total debt and expenditure on R\&D is positive for firms in the 'other manufacturing' sector, and negative for firms in the 'computer software development and services' sector. This suggests that firms in a sector typified by high levels of tangible assets ('other manufacturing') fund R\&D with debt, whereas firms in a sector typified by high levels of intangible assets ('computer software development and services') fund R\&D with external equity. Whilst results of the SUR models indicate the common influence of firm characteristics across sectors, as well as sectoral differences in sourcing finance, we are cautious in our interpretations and conclusions due to low levels of statistical significance.

\section{Conclusions}

This study empirically tested hypotheses formulated from theories of capital structure by investigating the influence of a number of firm characteristic determinants on SME financing. Results from multivariate models tested on survey data support a number of the propositions of agency and pecking order theories, confirming a number of findings of previous studies, albeit with a smaller sample. The results of the study emphasize (1) The increased use of internal equity as the firm develops over time, (2) the importance of the provision of collateral in alleviating information asymmetries and securing debt finance, and (3) the significant contribution of the firm owner through the contribution of equity and pledging personal assets as collateral for business loans.

The positive relationship between the use of retained profits and the age and size of the firm indicates that surviving firms are increasingly reliant on internal equity as accumulated profits are reinvested. This suggests a tendency to use capital which minimizes intrusion into the business, and is consistent with the POT. Another important source of internal equity is the personal funds of the firm owner, and funds of friends and family which are most important in firms with low turnover. Furthermore, results indicate that the firm owner contributes 'quasi-equity' in the form of the provision of personal assets as collateral for firm loans. These contributions emphasize the importance of the personal wealth of the firm owner in SME financing (Evans and Jovanovic, 1989), and indicate the significance of the risk taking propensity of the firm owner in the financing decision.

Results indicate that the use of long term debt financing is positively related with the size of the firm, and negatively related with firm age. The latter result suggests maturity matching, and indicates that firms increasingly use retained profits for investment projects as debt is retired over time. It is also indicative of the importance of the provision of fixed assets as collateral to secure debt finance. Results indicate that SMEs with a high level of fixed assets overcome problems of asymmetric information by pledging collateral to secure debt finance, as financial institutions seek to reduce agency costs of debt financing using asset-based lending techniques. In cases where there are insufficient lien-free firm assets to secure business loans, the personal assets of the firm owner are an important source of collateral. Debt secured 
on the personal assets of the firm owner is most prevalent among firms with low turnover, and among owners who also invest personal funds, and funds of friends and family in the firm.

Firms with a higher expenditure on R\&D use higher levels of external equity and lower levels of internal equity. This result suggests that high growth firms typically do not have sufficient internal finance to meet their investment needs, and confirms the finding of (Cressy and Olofsson, 1997) that owners of firms seeking to grow are less averse to ceding control than those not seeking growth. Ownership structure is also negatively related to external equity and positively related to internal equity, confirming the well documented desire for independence and control of closely held firms (Watson \& Wilson, 2002).

Analysis of the variation in the direction and magnitude of regression coefficients across sectors provides tentative evidence of the similarity of the influence of firm characteristics across sectors. Although a general lack of statistical significance precludes generalization of these findings, they indicate that a number of salient issues are relevant in sourcing investment finance for all SMEs, irrespective of sector. The common underlying factor in accessing external finance is the alleviation of information asymmetries, which is relatively easier for firms with a high level of fixed assets accessing debt markets, ceteris paribus. Firms engaged in a high level of intangible activity, with low turnover and a low level of tangible assets have a greater reliance on external equity. Thus, although the problems of information asymmetries may be universal, access to debt and equity markets is highly influenced by access to lien-free collateralizable assets and the investment preferences of investors.

\section{Policy and research implications}

Policy considerations emanating from our study are centered on the provision of the most important sources of finance for SMEs, namely retained profits and debt finance. Previous studies proposed that fiscal policies should incentivize reinvestment of earnings by providing tax incentives for a percentage of profits retained in the firm (Chittenden et al., 1998, Michaelas et al., 1999). The potential reduction in the taxation burden of SMEs under this proposal is of greater benefit in countries with high rates of corporate tax. The effectiveness of such a policy in Ireland is reduced because of the relatively low corporate tax rate of 12.5 percent. Possibly of more relevance is the disproportionate level of incentives for diverse investment options. Recent criticism publicised the greater concentration of resources in providing tax incentives for property investment compared with a lack of similar incentives for investing in the small business sector. A reconsideration of public policy to provide greater incentives for investing in SMEs would provide a 'more level playing field' for investment, and would raise levels of productive capital. Similarly, SME owners currently have a greater tax incentive to extract retained earnings from the firm and invest in a personal pension plan than to reinvest these funds in the firm. Public policy aimed at developing and expanding the capacity of the SME sector should consider making it more attractive for SME owners to reinvest retained profits than to extract them from the firm.

An interesting finding of our study is the positive relationship between the use of the firm owner's personal funds and funds from ' $\mathrm{f}$ ' connections and the provision of the personal assets of the firm owner as collateral to secure business debt. This heightened risk assumed by a number of business owners is likely to increase, as a number of authors (e.g. Tanaka, 2003) have indicated that smaller, riskier firms may 
have greater difficulty sourcing debt finance because of the more stringent capital adequacy requirements for banks under the Basel II proposals. This may result in an even wider occurrence of the practice of providing personal assets to secure business debt (including the family home), as firm owners attempt to secure funds for investment. This practice negates the limited liability status of incorporated firms and can cause considerable personal loss and distress to the firm owner and his family. Public policy initiatives should be designed to safeguard the home of the SME owner, and reduce the adverse social effects in the event of default on a business loan. It is important, however, in consideration of such a policy not to advance loans in excess of socially unproductive levels (De Meza and Webb, 2000). Additionally, financial institutions should consider reducing their dependency on asset-based lending technologies, concentrating instead on techniques such as financial statement lending. This, in turn, would reduce information asymmetries by obliging SMEs to provide detailed financial accounting information conforming with internationally accepted accounting principles.

Further research could test the issues raised in this study across a large representative sample of SMEs. It would be particularly beneficial to expand this study using surveys or in-depth interviews. This research method enables collection of detailed additional information on the process of raising finance and how this is influenced by factors such as past experience with financiers, the pledging of personal guarantees to secure debt finance, the percentage of the firm owner's wealth invested in the firm, issues of succession and a myriad of other factors. Integration of these contextual and explanatory factors into our model would provide a more holistic view of the financing decision. It would also allow a more in-depth examination of how the incremental financing decision of the SME owner changes through successive developmental stages of the firm. In light of the dependence of some firms on the personal sources of equity of the firm owner, along with the provision of personal assets as collateral to secure business loans, further studies may also benefit from integrating a personal risk measure for SME owners into the model. 
Ang, J. S., 1991, 'Small Business Uniqueness and the Theory of Financial Management', The Journal of Small Business Finance 1, 1-13.

Audretsch, D. B. \& Elston, J. A., 1997, 'Financing the German Mittelstand', Small Business Economics 9, 97-110.

Avery, R. B., Bostic, R. W. \& Samolyk, K. A., 1998, 'The Role of Personal Wealth in Small Business Finance', Journal of Banking and Finance 22, 1019-1061.

Baas, T. \& Schrooten, M., 2006, 'Relationship Banking and SMEs: A Theoretical Analysis', Small Business Economics 27, 127-137.

Balakrishnan, S. \& Fox, I., 1993, 'Asset Specificity, Firm Heterogeneity and Capital Structure', Strategic Management Journal 14, 3-16.

Baltagi, B. H., 2005, Econometric Analysis of Panel Data, Chichester: John Wiley and Sons.

Berger, A. N. \& Udell, G. F., 1990, 'Collateral, Loan Quality, and Bank Risk', Journal of Monetary Economics 25, 21-42.

Berger, A. N. \& Udell, G. F., 1998, 'The Economics of Small Business Finance: The Roles of Private Equity and Debt Markets in the Financial Growth Cycle', Journal of Banking and Finance 22, 613-673.

Berggren, B., Olofsson, C. \& Silver, L., 2000, 'Control Aversion and the Search for External Financing in Swedish SMEs', Small Business Economics 15, 233-242.

Bester, H., 1985, 'Screening vs. Rationing in Credit Markets with Imperfect Information', American Economic Review 75, 850-855.

Binks, M. R., Ennew, C. \& Reed, G. (1988) Small Business and Banks: A Two Nation Perspective. The Forum of Private Business, UK and the National Federation of Independent Businesses, USA.

Black, J., De Meza, D. \& Jeffreys, D., 1996, 'House Prices, the Supply of Collateral and the Enterprise Economy', The Economic Journal 106, 60-75.

Bougheas, S., 2004, 'Internal vs External Financing of R\&D', Small Business Economics 22, 11-17.

Cassar, G., 2004, 'The Financing of Business Start-ups', Journal of Business Venturing 19, 261-283.

Cassar, G. \& Holmes, S., 2003, 'Capital Structure and Financing of SMEs: Australian Evidence', Accounting and Finance 43, 123-147.

Chittenden, F., Hall, G. \& Hutchinson, P., 1996, 'Small Firm Growth, Access to Capital Markets and Financial Structure: Review of Issues and an Empirical Investigation', Small Business Economics 8, 56-67.

Chittenden, F., Poutziouris, P., Michaelas, N. \& Watt, T. (1998) The March 1998 Budget and Small Business Taxation. London, National Westminster Bank.

Coco, G., 2000, 'On the Use of Collateral', Journal of Economic Surveys 14, 191.

Cox, B. G., Elliehausen, G. E. \& Wolken, J. D. (1989) Surveying Small Businesses About Their Finances. Proceedings of the Section on Survey Research Methods, American Statistical Association. Virginia.

Cressy, R. (1993) Loan Commitments and Business Starts: An Empirical Investigation of UK data. Warwick Business School, CMSE Centre.

Cressy, R., 2006, 'Why Do Most Firms Die Young?' Small Business Economics 26, 103-116.

Cressy, R. \& Olofsson, C., 1997, 'The Financial Conditions for Swedish SMEs: Survey and Research Agenda', Small Business Economics 9, 179-194.

Curran, J. \& Blackburn, R. A., 2001, Researching the Small Enterprise, London: Sage. 
De Jong, A. \& Van Dijk, R., 2007, 'Determinants of Leverage and Agency Problems: A Regression Approach with Survey Data', The European Journal of Finance $13,565-593$.

De Meza, D. \& Webb, D. C., 2000, 'Does Credit Rationing Imply Insufficient Lending?' Journal of Public Economics 78, 215-234.

Deangelo, H. \& Masulis, R., 1980, 'Optimal Capital Structure Under Corporate and Personal Taxation.' Journal of Financial Economics. 8, 5-29.

Esperanca, J. P., Gama, A. P. M. \& Gulamhussen, M. A., 2003, 'Corporate Debt Policy of Small Firms: An Empirical (Re) Examination', Journal of Small Business and Enterprise Development 10, 62-80.

European Commission 2003 Recommendation 2003/361/EC concerning the definition of Small and Medium-sized Enterprises as published in the Official Journal of the European Union L 124, p. 36 of 20 May.

Evans, D. S. \& Jovanovic, B., 1989, 'An Estimated Model of Entrepreneurial Choice Under Liquidity Constraints', Journal of Political Economy 97, 808-827.

Fluck, Z., Holtz-Eakin, D. \& Rosen, H. S. (1998) Where Does the Money Come From ? The Financing of Small Entrepreneurial Enterprises. Metropolitan Studies Program Series. Occasional Paper no. 191, Center for Policy Research, Maxwell School of Citizenship and Public Affairs, Syracuse University.

Fu, T.-W., Ke, M.-C. \& Huang, Y.-S., 2002, 'Capital growth, Financing Source and Profitability of Small Businesses: Evidence From Taiwan Small Enterprises', Small Business Economics 18, 257-267.

Ghosh, S., 2007, 'Bank Debt Use and Firm Size: Indian Evidence', Small Business Economics 29, 15-23.

Hair, J. F., Black, W. C., Babin, B. J., Anderson, R. E. \& Tatham, R. L., 2006, Multivariate Data Analysis, Upper Saddle River, New Jersey: Pearson Prentice Hall.

Hall, B. H., 2002, 'The Financing of Research and Development', Oxford Review of Economic Policy 18, 35-51.

Hall, G., Hutchinson, P. \& Michaelas, N., 2004, 'Determinants of the Capital Structures of European SMEs', Journal of Business Finance \& Accounting 31, 711-728.

Hall, G., Hutchinson, P. J. \& Michaelas, N., 2000, 'Industry Effects on the Determinants of Unquoted SMEs' Capital Structure', International Journal of the Economics of Business 7, 297-312.

Hand, J. H., Lloyd, W. P. \& Rogow, R. B., 1982, 'Agency Relationships in the Close Corporation', Financial Management 11, 25-30.

Heyman, D., Deloof, M. \& Ooghe, H., 2008, 'The Financial Structure of Private Held Belgian Firms', Small Business Economics 30, 301-313.

Hogan, T. \& Hutson, E., 2005, 'Capital Structure in new Technology-Based Firms: Evidence From the Irish Software Sector.' Global Finance Journal 15, 369387.

Holmes, S. \& Kent, P., 1991, 'An Empirical Analysis of the Financial Structure of Small and Large Australian Manufacturing Enterprises', The Journal of Small Business Finance 1, 141-154.

Howorth, C. A., 2001, 'Small Firms' Demand for Finance: A Research Note', International Small Business Journal 19, 78-86.

Ibbotson, R. G., Sindelar, J. L. \& Ritter, J. (2001) Initial Public Offerings. IN CHEW, D. H. J. (Ed.) The New Corporate Finance. Where Theory Meets Practice. 3rd ed., McGraw Hill-Irwin. 
Jensen, M. C. \& Meckling, W. H., 1976, 'Theory of the Firm:Managerial Behaviour, Agency Costs and Ownership Structure', Journal of Financial Economics 3, 305-360.

Jordan, J., Lowe, J. \& Taylor, P., 1998, 'Strategy and Financial Policy in UK Small Firms', Journal of Business Finance \& Accounting 25, 1-27.

Kon, Y. \& Storey, D. J., 2003, 'A Theory of Discouraged Borrowers', Small Business Economics 21, 37-49.

Lopez-Gracia, J. \& Aybar-Arias, C., 2000, 'An Empirical Approach to the Financial Behaviour of Small and Medium Sized Companies', Small Business Economics 14, 55-63.

Manove, M., Padilla, A. J. \& Pagano, M., 2001, 'Collateral Versus Project Screening: A Model of Lazy Banks', RAND Journal of Economics 32, 726-744.

McConnell, J. J. \& Pettit, R. R. (1984) Application of the Modern Theory of Finance to Small Business Firms. IN HORVITZ, P. M. \& PETTIT, R. R. (Eds.) Small Business Finance. Greenwich, Connecticut, JAI Press.

Michaelas, N., Chittenden, F. \& Poutziouris, P., 1999, 'Financial Policy and Capital Structure Choice in UK SMEs: Empirical Evidence from Company Panel Data', Small Business Economics 12, 113-130.

Mishra, C. S. \& McConaughy, D. L., 1999, 'Founding Family Control and Capital Structure: The Risk of Loss of Control and the Aversion to Debt', Entrepreneurship Theory and Practice 23, 53-64.

Myers, S. C., 1984, 'The Capital Structure Puzzle', The Journal of Finance 39, 575592.

Myers, S. C. \& Majluf, N. S., 1984, 'Corporate Financing and Investment Decisions When Firms Have Information That Investors do not Have', Journal of Financial Economics June, 187-221.

Ou, C. \& Haynes, G. W., 2006, 'Acquisition of Additional Equity Capital by Small Firms - Findings from the National Survey of Small Business Finances', Small Business Economics 27, 157-168.

Pettit, R. R. \& Singer, R. F., 1985, 'Small Business Finance: A Research Agenda', Financial Management 14, 47-60.

Poutziouris, P., 2003, 'The Strategic Orientation of Owner-Managers of Small Ventures', International Journal of Entrepreneurial Behaviour \& Research 9, 185-214.

Poutziouris, P., Chittenden, F. \& Michaelas, N. (1998) The Financial Affairs of Private Companies. Tilney Fund Management, Liverpool.

Poutziouris, P. Z., 2001, 'The Views of Family Companies on Venture Capital: Empirical Evidence from the UK Small to Medium-Size Enterprising Economy', Family Business Review 14, 277-291.

Smart, S. B., Megginson, W. L. \& Gitman, L. J., 2007, Corporate Finance, Mason: Thomson South-Western.

Sogorb Mira, F., 2005, 'How SME Uniqueness Affects Capital Structure: Evidence From a 1994-1998 Spanish Data Panel', Small Business Economics 25, 447457.

Storey, D. J., 1994, Understanding the Small Business Sector, London: Routledge.

Tanaka, M., 2003, 'The Macroeconomic Implications of the New Basel Accord', CESifo Economic Studies 49, 217-232.

Titman, S. \& Wessels, R., 1988, 'The Determinants of Capital Structure Choice', The Journal of Finance XLIII, 1-19. 
Van Der Wijst, N. \& Thurik, R., 1993, 'Determinants of Small Firm Debt Ratios: An Analysis of Retail Panel Data', Small Business Economics 5, 55-65.

Voordeckers, W. \& Steijvers, T., 2006, 'Business Collateral and Personal Commitments in SME Lending', Journal of Banking \& Finance 30, 30673086.

Watson, R. \& Wilson, N., 2002, 'Small and Medium Size Enterprise Financing: A Note on Some of the Empirical Implications of a Pecking Order', Journal of Business Finance \& Accounting 29, 557-579.

Westhead, P. \& Storey, D. J., 1997, 'Financial Constraints on the Growth of High Technology Small Firms in the United Kingdom', Applied Financial Economics 7, 197-201.

Zellner, A., 1962, 'An Efficient Method of Estimating Seemingly Unrelated Regressions and Tests for Aggregation Bias', Journal of the American Statistical Association 57, 348-368.

Zingales, L., 2000, 'In Search of New Foundations', The Journal of Finance 55, 1623 1653. 
Table 1. Age, industry and turnover profile of respondents

\begin{tabular}{|c|c|c|c|c|c|}
\hline Panel A. & & Panel B. & & Panel C. & \\
\hline $\begin{array}{l}\text { Age of } \\
\text { Firm }\end{array}$ & $\begin{array}{c}\text { Proportion } \\
\text { of } \\
\text { Sample }(\%)\end{array}$ & Industry Type & $\begin{array}{c}\text { Proportion } \\
\text { of } \\
\text { Sample } \\
(\%)\end{array}$ & Turnover & $\begin{array}{c}\text { Proportion } \\
\text { of } \\
\text { Sample }(\%)\end{array}$ \\
\hline$<5$ years & 5.1 & $\begin{array}{l}\text { Metal manufacturing } \\
\text { and Engineering }\end{array}$ & 15.6 & $<€ 1 \mathrm{~m}$ & 3.1 \\
\hline 5-9 years & 17.2 & Other manufacturing & 21.3 & $€ 1 \mathrm{~m}-€ 2.99 \mathrm{~m}$ & 11.6 \\
\hline 10-14 years & 12.8 & $\begin{array}{l}\text { Computer software } \\
\text { development/services }\end{array}$ & 17.3 & $€ 3 \mathrm{~m}-€ 4.99 \mathrm{~m}$ & 13.3 \\
\hline 15-19 years & 10.4 & $\begin{array}{l}\text { Distribution, Retail, } \\
\text { Hotels \& Catering }\end{array}$ & 27.5 & $€ 5 \mathrm{~m}-€ 9.99 \mathrm{~m}$ & 31.6 \\
\hline 20-29 years & 21.5 & Other services & 9.1 & $€ 10 \mathrm{~m}-€ 20 \mathrm{~m}$ & 32.0 \\
\hline$>30$ years & 33 & Other & 9.2 & $€ 20 \mathrm{~m}-€ 50 \mathrm{~m}$ & 8.5 \\
\hline
\end{tabular}

Table 2. Description of dependent variables

\begin{tabular}{ll}
\hline Dependent Variable & Description of Variable \\
\hline Personal Savings and 'f' & Personal savings of founder(s), funds from friends and Family (as \\
connections (PERF) & a percentage of total financing) \\
Retained Profits (RETП) & Retained Profits (as a percentage of total financing) \\
External Equity (EXTEQ) & Venture Capital + Business Angels and Private Investors+ \\
& Government Grants and Equity (as a percentage of total financing) \\
Long-term Debt (LTD) & Long term debt (as a percentage of total financing) \\
Short-term Debt (STD) & Short term bank loans and overdraft (as a percentage of total \\
& financing) \\
\hline
\end{tabular}

Table 3. Means and standard deviations of dependent variables across sectors

\begin{tabular}{lccccc}
\hline Industry & $\begin{array}{c}\text { Personal } \\
\text { savings of } \\
\text { founder(s), } \\
\text { funds from } \\
\text { friends \& } \\
\text { family }\end{array}$ & $\begin{array}{l}\text { Retained } \\
\text { Profits }\end{array}$ & $\begin{array}{c}\text { Short } \\
\text { term bank } \\
\text { loans \& } \\
\text { overdraft }\end{array}$ & $\begin{array}{c}\text { Long term } \\
\text { debt } \\
\text { instruments }\end{array}$ & $\begin{array}{c}\text { External } \\
\text { Equity }\end{array}$ \\
\hline $\begin{array}{l}\text { Metal manufacturing } \\
\text { and Engineering }\end{array}$ & $.148(.27)$ & $.498(.41)$ & $.135(.26)$ & $.028(.09)$ & $.075(.17)$ \\
$\begin{array}{l}\text { Other manufacturing } \\
\text { Computer software }\end{array}$ & $.070(.17)$ & $.395(.36)$ & $.205(.25)$ & $.116(.23)$ & $.054(.16)$ \\
$\begin{array}{l}\text { development/services } \\
\text { Distribution, Retail, }\end{array}$ & $.095(.20)$ & $.176(.33)$ & $.194(.35)$ & $.028(.10)$ & $.327(.41)$ \\
$\begin{array}{l}\text { Hotels \& Catering } \\
\text { Other services }\end{array}$ & $.075(.22)$ & $.324(.39)$ & $.232(.33)$ & $.093(.25)$ & $.054(.19)$ \\
$\begin{array}{l}\text { Other } \\
\text { Total }\end{array}$ & $.104(.26)$ & $.393(.41)$ & $.194(.33)$ & $.097(.21)$ & $.012(.05)$ \\
$\begin{array}{l}\text { One way Anova F } \\
\text { statistic }\end{array}$ & $.096(.22)$ & $.350(.45)$ & $.120(.23)$ & $.047(.13)$ & $.212(.36)$ \\
\hline
\end{tabular}

**** Statistically significant at the $99 \%$ and $95 \%$ levels of confidence respectively. 
Table 4. Description of independent variables

\begin{tabular}{ll}
\hline Independent Variable & Description of Variable \\
\hline AGE & $\begin{array}{l}\text { Age of the firm in years at the time of the survey (categorical } \\
\text { variable) } \\
\text { Gross Sales turnover of the firm (categorical variable) } \\
\text { PIZE }\end{array}$ \\
R\&D & $\begin{array}{l}\text { (categorical variable) } \\
\text { Closely held ownership of firm (Dichotomous dummy variable) }\end{array}$ \\
OWN & $\begin{array}{l}\text { Percentage of debt secured by liens on the fixed assets of the firm. } \\
\text { Internal Collateral } \\
\text { (INTCOLL) }\end{array}$ \\
$\begin{array}{l}\text { Owner's Collateral } \\
\text { (OWNCOLL) }\end{array}$ & Percentage of debt secured by personal assets of firm owner \\
\hline
\end{tabular}

Table 5. Pearson correlation coefficients.

\begin{tabular}{lccccc}
\hline & AGE & SIZE & R\&D & OWN & INTCOLL \\
AGE & & & & & \\
SIZE & $.269^{*}$ & & & & \\
R\&D & $-.381^{*}$ & $-.377^{*}$ & & & \\
OWN & $.378^{*}$ & .078 & $-.256^{*}$ & & \\
INTCOLL & $.194^{*}$ & $.232^{*}$ & $-.211^{*}$ & .069 & \\
EXTCOLL & $-.157^{*}$ & -.159 & .059 & .032 & $-.219^{*}$ \\
\hline
\end{tabular}

${ }^{*}$ Correlation is statistically significant at the $99 \%$ level of confidence (2-tailed)

Table 6. Estimated ordinary least squares regression coefficients.

\begin{tabular}{|c|c|c|c|c|c|c|c|}
\hline & \multicolumn{2}{|c|}{ Internal Equity } & \multirow{2}{*}{$\begin{array}{l}\text { External } \\
\text { Equity } \\
\text { EXTEQ }\end{array}$} & \multicolumn{2}{|l|}{ Debt } & \multicolumn{2}{|c|}{$\begin{array}{l}\text { Collinearity } \\
\text { Statistics }\end{array}$} \\
\hline & PERF & RET】 & & STD & LTD & Tolerance & VIF \\
\hline Independent & Model 1 & Model 2 & Model 3 & Model 4 & Model 5 & & \\
\hline Variables & $\beta$ & $\beta$ & $\beta$ & $\beta$ & $\beta$ & & \\
\hline AGE & $\begin{array}{l}-.002 \\
(-.204)\end{array}$ & $\begin{array}{l}.030 * * \\
(2.01)\end{array}$ & $\begin{array}{l}-.008 \\
(-.806)\end{array}$ & $\begin{array}{l}.008 \\
(.667)\end{array}$ & $\begin{array}{l}-.015^{*} \\
(-1.90)\end{array}$ & .724 & 1.38 \\
\hline SIZE & $\begin{array}{l}-.031^{*} \\
(-2.92)\end{array}$ & $\begin{array}{l}.035^{*} \\
(1.80)\end{array}$ & $\begin{array}{l}.010 \\
(.745)\end{array}$ & $\begin{array}{l}.009 \\
(.583)\end{array}$ & $\begin{array}{l}.016^{*} \\
(1.63)\end{array}$ & .805 & 1.24 \\
\hline$R \& D$ & $\begin{array}{l}.007 \\
(.404)\end{array}$ & $\begin{array}{c}-.098 * * * \\
(-3.22)\end{array}$ & $\begin{array}{c}.113 * * * \\
(5.83)\end{array}$ & $\begin{array}{l}-.011 \\
(-.458)\end{array}$ & $\begin{array}{l}-.001 \\
(-.086)\end{array}$ & .760 & 1.31 \\
\hline OWN & $\begin{array}{l}.028 \\
(1.04)\end{array}$ & $\begin{array}{l}.078 \\
(1.60)\end{array}$ & $\begin{array}{c}-.158 * * * \\
(-5.05)\end{array}$ & $\begin{array}{l}-.005 \\
(-.115)\end{array}$ & $\begin{array}{l}-.011 \\
(-.427)\end{array}$ & .827 & 1.21 \\
\hline OWNCOLL & $\begin{array}{l}.260^{*} \\
(5.59)\end{array}$ & $\begin{array}{c}-.238 * * * \\
(-2.86)\end{array}$ & $\begin{array}{c}-.044 \\
(-.823)\end{array}$ & $\begin{array}{l}.129 * \\
(1.89)\end{array}$ & $\begin{array}{c}.014 \\
(.330)\end{array}$ & .919 & 1.09 \\
\hline INTCOLL & $\begin{array}{c}-.033 \\
(-1.18)\end{array}$ & $\begin{array}{c}-.135 * * * \\
(-2.71)\end{array}$ & $\begin{array}{l}-.040 \\
(-1.27)\end{array}$ & $\begin{array}{c}.147 * * * \\
(3.60)\end{array}$ & $\begin{array}{l}.110 * * * \\
(4.19)\end{array}$ & .882 & 1.13 \\
\hline Constant & $\begin{array}{l}.186^{*} \\
(2.53)\end{array}$ & $\begin{array}{l}.293 * * \\
(2.23)\end{array}$ & $\begin{array}{l}.022 \\
(.265)\end{array}$ & $\begin{array}{l}.074 \\
(.684)\end{array}$ & $\begin{array}{c}.033 \\
(.480)\end{array}$ & & \\
\hline $\begin{array}{l}\text { Adjusted R }{ }^{2} \\
\text { "F" Value }\end{array}$ & $\begin{array}{c}16.2 \\
10.168\end{array}$ & $\begin{array}{l}14.9 \\
9.28\end{array}$ & $\begin{array}{c}25.9 \\
17.573\end{array}$ & $\begin{array}{c}4.5 \\
3.218\end{array}$ & $\begin{array}{l}6.5 \\
4.3\end{array}$ & & \\
\hline $\begin{array}{l}\text { Significance of } \\
\text { "F" }\end{array}$ & .000 & .000 & .000 & .005 & .000 & & \\
\hline
\end{tabular}

$\mathrm{t}$ statistics in parentheses. $* * *, * *, *$ statistically significant at the $99 \%, 95 \%$ and $90 \%$ level of confidence respectively 
Table 7. Summary of the relationships between variables

\begin{tabular}{cccccc}
\hline & PERF & RETD & EXTEQ & STD & LTD \\
\hline Independent & Model 1 & Model 2 & Model 3 & Model 4 & Model 5 \\
Variables & $\beta$ & $\beta$ & $\beta$ & $\beta$ & $\beta$ \\
\hline AGE & $-/(-)$ & $+/(+)$ & $-/(-)$ & $+/(-)$ & $-/(-)$ \\
SIZE & $-/(-)$ & $+/(+)$ & $+/(+)$ & $+/(+)$ & $+/(+)$ \\
R\&D & $+/(+)$ & $-/(-)$ & $+/(+)$ & $-/(+/-)$ & $-/(-)$ \\
OWN & $+/(+)$ & $+/(+)$ & $-/(-)$ & $-/(-)$ & $-/(-)$ \\
OWNCOLL & $+/(+)$ & $-/(-)$ & $-/(-)$ & $+/(+)$ & $+/(+)$ \\
INTCOLL & $-/(-)$ & $-/(-)$ & $-/(-)$ & $+/(+)$ & $+/(+)$ \\
\hline
\end{tabular}

Hypothesized relationships in parentheses.

Table 8. Regression coefficients of seemingly unrelated regression models employing 'personal savings \& ' $\mathrm{f}$ ' connections' as the dependent variable.

\begin{tabular}{|c|c|c|c|c|c|c|c|}
\hline & ALL & METAL & MANU & COMPU & HOTEL & SERVS & OTHER \\
\hline \multirow[t]{2}{*}{$\mathrm{AGE}$} & -.002 & .018 & -.006 & .005 & -.011 & -.010 & .000 \\
\hline & $(-.207)$ & $(.531)$ & $(-.448)$ & $(.178)$ & $(-.744)$ & $(-.375)$ & $(-.010)$ \\
\hline \multirow[t]{2}{*}{ SIZE } & $-.031 * * *$ & $-.089 * *$ & $-.063 * * *$ & -.016 & -.008 & -.032 & .023 \\
\hline & $(-2.96)$ & $(-2.52)$ & $(-3.25)$ & $(-.627)$ & $(-.368)$ & $(-.868)$ & $(1.02)$ \\
\hline \multirow[t]{2}{*}{$\mathrm{R} \& \mathrm{D}$} & .007 & .031 & .018 & -.009 & $.081 * *$ & .044 & .038 \\
\hline & $(.409)$ & $(.452)$ & $(.533)$ & $(-.292)$ & $(2.07)$ & $(.558)$ & (1.09) \\
\hline \multirow[t]{2}{*}{ OWN } & .028 & .031 & -.023 & -.042 & -.021 & .137 & .068 \\
\hline & $(1.06)$ & $(.309)$ & $(-.459)$ & $(-.612)$ & $(-.408)$ & $(1.66)$ & (1.57) \\
\hline \multirow[t]{2}{*}{ OWNCOLL } & $.260 * * *$ & .123 & .148 & .155 & $.344 * * *$ & $.597 * * *$ & $.560 * * *$ \\
\hline & $(5.66)$ & $(.697)$ & (1.54) & $(1.45)$ & $(5.17)$ & $(2.94)$ & $(5.22)$ \\
\hline \multirow[t]{2}{*}{ INTCOLL } & -.033 & -.126 & .008 & -.040 & .017 & -.025 & -.035 \\
\hline & $(-1.20)$ & $(-1.46)$ & $(.161)$ & $(-.529)$ & $(.325)$ & $(-.283)$ & $(-.721)$ \\
\hline \multirow[t]{2}{*}{ Constant } & $.186^{* *}$ & .370 & $331 * *$ & .159 & -.003 & .094 & -.140 \\
\hline & $(2.56)$ & $(1.58)$ & $(2.53)$ & $(.930)$ & $(-.023)$ & $(.433)$ & $(-.834)$ \\
\hline
\end{tabular}

$\mathrm{t}$ statistics in parentheses. ${ }^{* *}, * *, *$ statistically significant at the $99 \%, 95 \%$ and $90 \%$ level of confidence respectively

Table 9. Regression coefficients of seemingly unrelated regression models employing 'retained profits' as the dependent variable.

\begin{tabular}{|c|c|c|c|c|c|c|c|}
\hline & ALL & METAL & MANU & COMPU & HOTEL & SERVS & OTHER \\
\hline \multirow[t]{2}{*}{ AGE } & $.030 * *$ & -.039 & .023 & .034 & .030 & .035 & .000 \\
\hline & $(2.04)$ & $(-.782)$ & $(.858)$ & $(.837)$ & (.998) & $(.769)$ & $(.004)$ \\
\hline \multirow[t]{2}{*}{ SIZE } & $.035 *$ & .076 & $.098 * *$ & -.009 & $.069 *$ & .031 & -.058 \\
\hline & $(1.82)$ & (1.44) & $(2.35)$ & $(-.223)$ & $(1.71)$ & (.499) & $(-.781)$ \\
\hline \multirow[t]{2}{*}{$\mathrm{R} \& \mathrm{D}$} & $-.098 * * *$ & -.148 & -.111 & -.053 & $-.126^{*}$ & $-.256^{*}$ & $-.333 * * *$ \\
\hline & $(-3.26)$ & $(-1.44)$ & $(-1.50)$ & $(-1.09)$ & $(-1.65)$ & $(-1.87)$ & $(-3.00)$ \\
\hline \multirow[t]{2}{*}{ OWN } & $.078 *$ & $.266^{*}$ & .108 & .032 & .116 & .036 & $.290 * *$ \\
\hline & (1.62) & (1.81) & (1.00) & $(.299)$ & (1.14) & $(.252)$ & $(2.09)$ \\
\hline \multirow[t]{2}{*}{ OWNCOLL } & $-.238 * * *$ & -.208 & .097 & -.220 & $-.330 * * *$ & -.325 & -.203 \\
\hline & $(-2.89)$ & $(-.795)$ & $(.475)$ & $(-1.32)$ & $(-2.55)$ & $(-.929)$ & $(-.590)$ \\
\hline \multirow[t]{2}{*}{ INTCOLL } & $-.135 * * *$ & .006 & -.118 & .071 & $-.288 * * *$ & $-.267^{*}$ & $-.381 * *$ \\
\hline & $(-2.74)$ & $(.047)$ & $(-1.17)$ & $(.611)$ & $(-2.90)$ & $(-1.76)$ & $(-2.43)$ \\
\hline \multirow[t]{2}{*}{ Constant } & $.293 * *$ & .469 & .064 & .251 & .180 & .598 & $1.52 * * *$ \\
\hline & $(2.26)$ & $(1.35)$ & $(.229)$ & $(.941)$ & $(.677)$ & (1.59) & $(2.83)$ \\
\hline
\end{tabular}

$\mathrm{t}$ statistics in parentheses. $* * *, * *, *$ statistically significant at the $99 \%, 95 \%$ and $90 \%$ level of confidence respectively 
Table 10. Regression coefficients of seemingly unrelated regression models employing 'external equity' as the dependent variable.

\begin{tabular}{|c|c|c|c|c|c|c|c|}
\hline & ALL & METAL & MANU & COMPU & HOTEL & SERVS & OTHER \\
\hline \multirow[t]{2}{*}{ AGE } & -.008 & -0.017 & 0.004 & 0.005 & -0.013 & 0.004 & 0.032 \\
\hline & $(-.816)$ & $(-.859)$ & $(.288)$ & $(.123)$ & $(-.871)$ & $(.594)$ & $(.831)$ \\
\hline \multirow[t]{2}{*}{ SIZE } & .010 & -0.008 & -0.001 & $0.082 * *$ & 0.019 & -0.005 & 0.056 \\
\hline & $(.754)$ & $(-.374)$ & $(-.070)$ & $(2.10)$ & (.919) & $(-.618)$ & (1.03) \\
\hline \multirow[t]{2}{*}{ R\&D } & $.113 * * *$ & 0.062 & -0.044 & $0.203 * * *$ & -0.001 & -0.015 & $0.148 * *$ \\
\hline & $(5.90)$ & (1.54) & $(-1.27)$ & $(4.20)$ & $(-.014)$ & $(-.792)$ & $(2.32)$ \\
\hline \multirow[t]{2}{*}{ OWN } & $-.158 * * *$ & $-0.127 * *$ & -0.015 & -0.151 & $-0.151 * * *$ & 0.013 & $-0.243 * *$ \\
\hline & $(-5.12)$ & $(-2.19)$ & $(-.303)$ & $(-1.43)$ & $(-2.92)$ & $(.655)$ & $(-2.39)$ \\
\hline \multirow[t]{2}{*}{ OWNCOLL } & -.044 & 0.076 & -0.109 & -0.171 & .020 & -0.019 & -0.008 \\
\hline & $(-.833)$ & $(.734)$ & $(-1.14)$ & $(-1.03)$ & $(.303)$ & $(-.393)$ & $(-.033)$ \\
\hline \multirow[t]{2}{*}{ INTCOLL } & -.040 & 0.056 & -0.034 & $-0.222 *$ & -0.056 & -0.011 & $0.203^{*}$ \\
\hline & $(-1.28)$ & (1.10) & $(-.712)$ & $(-1.92)$ & $(-1.10)$ & $(-.537)$ & $(1.77)$ \\
\hline \multirow[t]{2}{*}{ Constant } & .022 & 0.143 & 0.170 & -0.365 & 0.171 & 0.037 & $-0.728^{*}$ \\
\hline & $(.269)$ & (1.04) & $(1.29)$ & $(-1.38)$ & $(1.27)$ & $(.728)$ & $(-1.84)$ \\
\hline
\end{tabular}

t statistics in parentheses. $* * *, * *, *$ statistically significant at the $99 \%, 95 \%$ and $90 \%$ level of confidence respectively

Table 11. Regression coefficients of seemingly unrelated regression models employing 'short term debt' as the dependent variable.

\begin{tabular}{|c|c|c|c|c|c|c|c|}
\hline & ALL & METAL & MANU & COMPU & HOTEL & SERVS & OTHER \\
\hline \multirow[t]{2}{*}{ AGE } & .008 & -0.005 & $0.050 * * *$ & 0.036 & 0.012 & -0.050 & 0.027 \\
\hline & $(.676)$ & $(-.167)$ & $(2.67)$ & $(.941)$ & $(.471)$ & $(-1.30)$ & $(.786)$ \\
\hline \multirow[t]{2}{*}{ SIZE } & .009 & 0.052 & -0.035 & -0.016 & 0.012 & 0.019 & 0.025 \\
\hline & $(.590)$ & $(1.61)$ & $(-1.20)$ & $(-.443)$ & $(.343)$ & $(.356)$ & $(.526)$ \\
\hline \multirow[t]{2}{*}{$R \& D$} & -.011 & 0.067 & $0.108 * *$ & $-0.118 * *$ & 0.023 & 0.059 & 0.040 \\
\hline & $(-.464)$ & (1.06) & $(2.11)$ & $(-2.57)$ & $(.341)$ & $(.500)$ & $(.546)$ \\
\hline \multirow[t]{2}{*}{ OWN } & -.005 & 0.028 & -0.012 & -0.163 & -0.076 & $0.206^{*}$ & $0.180^{*}$ \\
\hline & $(-.116)$ & $(.314)$ & $(-.156)$ & $(-1.63)$ & $(-.843)$ & $(1.70)$ & (1.97) \\
\hline \multirow[t]{2}{*}{ OWNCOLL } & $.129 * *$ & 0.222 & 0.153 & $0.445 * * *$ & 0.056 & -0.314 & -0.077 \\
\hline & (1.91) & (1.38) & (1.07) & $(2.84)$ & $(.496)$ & $(-1.05)$ & $(-.338)$ \\
\hline \multirow[t]{2}{*}{ INTCOLL } & $.147 * * *$ & $0.200 * *$ & $0.119^{*}$ & $0.206^{*}$ & $0.264 * * *$ & 0.029 & -0.040 \\
\hline & $(3.64)$ & $(2.54)$ & $(1.70)$ & (1.88) & $(3.03)$ & $(.223)$ & $(-.392)$ \\
\hline \multirow[t]{2}{*}{ Constant } & .074 & -0.281 & -0.147 & 0.401 & 0.021 & 0.121 & -0.243 \\
\hline & $(.692)$ & $(-1.31)$ & $(-.758)$ & $(1.60)$ & $(.092)$ & $(.378)$ & $(-.689)$ \\
\hline
\end{tabular}

t statistics in parentheses. $* * *, * *, *$ statistically significant at the $99 \%, 95 \%$ and $90 \%$ level of confidence respectively

Table 12. Regression coefficients of seemingly unrelated regression models employing 'long term debt' as the dependent variable.

\begin{tabular}{|c|c|c|c|c|c|c|c|}
\hline & ALL & METAL & MANU & COMPU & HOTEL & SERVS & OTHER \\
\hline \multirow[t]{2}{*}{ AGE } & $-.015^{*}$ & 0.013 & $-0.033 * *$ & $-0.031 * * *$ & -0.004 & -0.017 & 0.005 \\
\hline & $(-1.92)$ & (1.07) & $(-2.02)$ & $(-2.64)$ & $(-.197)$ & $(-.808)$ & $(.220)$ \\
\hline \multirow[t]{2}{*}{ SIZE } & $.016^{*}$ & 0.004 & 0.040 & 0.011 & -0.018 & -0.014 & 0.008 \\
\hline & $(1.65)$ & $(.329)$ & (1.58) & $(.945)$ & $(-.644)$ & $(-.488)$ & $(.285)$ \\
\hline \multirow{2}{*}{$\mathrm{R} \& \mathrm{D}$} & -.001 & -0.004 & 0.001 & -0.019 & 0.015 & $0.122 *$ & -0.026 \\
\hline & $(-.086)$ & $(-.151)$ & $(.027)$ & $(-1.39)$ & $(.269)$ & (1.93) & $(-.601)$ \\
\hline \multirow[t]{2}{*}{ OWN } & -.011 & -0.028 & $-0.165^{* *}$ & 0.010 & 0.027 & -0.109 & 0.057 \\
\hline & $(-.431)$ & $(-.821)$ & $(-2.52)$ & $(.341)$ & $(.361)$ & $(-1.66)$ & $(1.05)$ \\
\hline \multirow[t]{2}{*}{ OWNCOLL } & .014 & -0.022 & -0.016 & -0.026 & 0.042 & -0.194 & 0.194 \\
\hline & $(.334)$ & $(-.361)$ & $(-.129)$ & $(-.542)$ & $(.453)$ & $(-1.19)$ & $(1.44)$ \\
\hline \multirow[t]{2}{*}{ INTCOLL } & $110 * * *$ & 0.049 & 0.082 & $0.109 * * *$ & 0.106 & $0.202 * * *$ & 0.043 \\
\hline & $(5.3)$ & (1.62) & $(1.34)$ & $(3.29)$ & (1.48) & $(2.87)$ & $(.701)$ \\
\hline \multirow[t]{2}{*}{ Constant } & .033 & -0.040 & 0.178 & 0.104 & 0.098 & 0.050 & -0.018 \\
\hline & $(.486)$ & $(-.493)$ & $(1.05)$ & (1.38) & $(.512)$ & $(.289)$ & $(-.087)$ \\
\hline
\end{tabular}
$\mathrm{t}$ statistics in parentheses. $* * *, * *, *$ statistically significant at the $99 \%, 95 \%$ and $90 \%$ level of confidence respectively 
Table 13. Regression coefficients of seemingly unrelated regression models employing 'total debt' as the dependent variable.

\begin{tabular}{|c|c|c|c|c|c|c|c|}
\hline & ALL & METAL & MANU & COMPU & HOTEL & SERVS & OTHER \\
\hline \multirow[t]{2}{*}{ AGE } & -.007 & .007 & .017 & .006 & .008 & $-.067 *$ & .032 \\
\hline & $(-.521)$ & $(.237)$ & $(.716)$ & $(.157)$ & $(.286)$ & $(-1.70)$ & $(.933)$ \\
\hline \multirow[t]{2}{*}{ SIZE } & .026 & $.057^{*}$ & .005 & -.006 & -.006 & .005 & .033 \\
\hline & (1.54) & $(1.73)$ & $(.141)$ & $(-.172)$ & $(-.169)$ & $(.089)$ & $(.680)$ \\
\hline \multirow[t]{2}{*}{$\mathrm{R} \& \mathrm{D}$} & -.013 & .063 & $.109 *$ & $-.137 * * *$ & .038 & .181 & .013 \\
\hline & $(-.488)$ & (.994) & (1.69) & $(-3.24)$ & $(.518)$ & (1.51) & $(.177)$ \\
\hline \multirow[t]{2}{*}{ OWN } & -.015 & .000 & $-.176^{*}$ & $-.152 *$ & -.049 & .097 & $.238 * *$ \\
\hline & $(-.363)$ & $(.001)$ & $(-1.88)$ & $(-1.65)$ & $(-.505)$ & $(.780)$ & $(2.62)$ \\
\hline \multirow[t]{2}{*}{ OWNCOLL } & $.143 * *$ & .199 & .137 & $419 * * *$ & .098 & -.508 & .119 \\
\hline & (1.99) & $(1.23)$ & $(.761)$ & $(2.90)$ & (.799) & $(-1.66)$ & $(.527)$ \\
\hline \multirow[t]{2}{*}{ INTCOLL } & $257 * * *$ & $248 * * *$ & $201 * *$ & $.315 * * *$ & $370 * * *$ & $.230 *$ & .000 \\
\hline & $(5.96)$ & $(3.14)$ & $(2.28)$ & $(3.11)$ & $(3.91)$ & $(1.74)$ & $(-.004)$ \\
\hline \multirow[t]{2}{*}{ Constant } & .107 & -.321 & .031 & $.505 * *$ & .119 & .171 & -.258 \\
\hline & $(.942)$ & $(-1.49)$ & $(.128)$ & $(2.18)$ & $(.470)$ & $(.523)$ & $(-.733)$ \\
\hline
\end{tabular}

$\mathrm{t}$ statistics in parentheses. $* * *, * *, *$ statistically significant at the $99 \%, 95 \%$ and $90 \%$ level of confidence respectively. 